\title{
Varicella zoster immune globulin use in neonates and infants
}

$\mathrm{V}$ aricella zoster virus can be transmitted perinatally from an infected mother to her child - if the maternal varicella rash appears shortly before delivery, the newborn is at increased risk of developing severe complicated varicella. of 13 cases of neonatal varicella reported in the literature with onset of maternal rash four days or less before delivery, four died. All 23 cases whose mothers developed a rash five days or more preceding delivery survived (1). In a British study of neonates exposed to maternal varicella perinatally, many of those born up to seven days after onset of maternal rash had no detectable antibody to varicella zoster virus and thus were considered susceptible to severe disease (2).

Maternal zoster does not put neonates at risk of severe varicella. Varicella zoster immune globulin (VZIG) has been shown to prevent or attenuate varicella effectively in immunocompromised patients exposed to the virus (3). When administered to neonates exposed to maternal chickenpox, VZIG effectively attenuates infection, although it has little effect on the rate of infection $(1,2)$. Because of this, advisory committees both in the United States and Canada have recommended the prophylactic administration of VZIG to neonates whose mothers develop varicella between five days before and two days after delivery. It must be noted that severe varicella may occur in neonates despite the appropriate use of VZIG (4-6).

Anecdotal reports of severe varicella in neonates of nonimmune mothers following postnatal exposure to varicella zoster virus have raised the issue of the use of prophylactic VZIG in such infants $(7,8)$. A survey of pediatric infectious disease experts revealed that $38 \%$ of those responding would have given VZIG prophylaxis to a neonate postnatally exposed to varicella virus if the mother was not immune (9). This percentage increased among those who had encountered previous cases of severe neonatal varicella. In an accompanying com-

All material presented in Pediatric Infectious Disease Notes has been reviewed and approved by the chairperson, Canadian Paediatric Society Board and representative members of the Canadian Paediatric Society Committee on Infectious Diseases and Immunization

Correspondence: Infectious Diseases and Immunization Committee, Canadian Paediatric Society, 401 Smyth Road, Ottawa, Ontario K1H 8L1. Telephone 613-737-2728,

fax $613-737-2794$ mentary (10), it was pointed out that varicella acquired in the first year of life was more frequently fatal compared with disease in older children, but that the fatality rate remained exceedingly low $(8 / 100,000$ cases) (11), and that overuse of VZIG might jeopardize availability of the product for high risk situations.

What are the appropriate uses of prophylactic VZIG in the newborn (Table 1)?

- Because of the greatly increased risk of severe disease if infection is transmitted, newborns of mothers who develop varicella rash between five days before and two days after delivery should receive a $125 \mathrm{U}$ dose of prophylactic VZIG. Some experts would extend this period to seven days antepartum (2).

- Prophylaxis is not indicated for the newborn if the mother develops rash more than seven days before delivery.

- For postnatal exposure in the first month of life to staff, mothers of other children, visitors or other neonates with varicella infection, use of VZIG is not recommended except in the following:

- neonates born after a pregnancy of less than 28 weeks' duration or who weigh less than $1000 \mathrm{~g}$ at birth - they are frequently unprotected despite maternal immunity because of inefficient transplacental transport of antibody before week 28 of gestation;

- newborns who require intensive care, regardless of maternal immune status or gestational age - these children will often sustain a rapid drop in levels of maternally derived antibody because of diagnostic and/or therapeutic interventions, and may be at risk of more severe disease because of their underlying conditions $(9,12)$;

- neonates with known or suspected immunodeficiency born to nonimmune mothers.

- VZIG is also recommended for neonates born to nonimmune mothers who are about to be discharged when there are active cases of varicella at home and where exposure is unavoidable. In this situation, the 
TABLE 1

Indication for varicella zoster immune globulin

\begin{tabular}{|c|c|c|c|c|}
\hline & \multicolumn{2}{|c|}{ Neonates } & \multicolumn{2}{|c|}{ 1-12 months of age } \\
\hline & \multicolumn{4}{|c|}{ Mother } \\
\hline & Immune & Nonimmune & Immune & Nonimmune \\
\hline Need for intensive care in NICU & + & + & + & + \\
\hline Immunodeficiency & + & + & + & + \\
\hline
\end{tabular}

NICU Neonatal intensive care unit

aim is to avoid disruption of routine care. Administration of VZIG to the mother should also be considered.

- Neonates exposed perinatally to maternal zoster do not need to receive VZIG.

- Use of prophylactic VZIG following exposure beyond the neonatal period should be reserved for those who are recognized as being at increased risk of a severe illness, ie, infants with a severe underlying skin condition, infants with known or suspected immunodeficiency and infants born before 28 weeks' gestation, unless they have been discharged from hospital and have reached term weight.

\section{REFERENCES}

1. Gershon AA. Chickenpox, measles and mumps. In: Remington JS, Klein JO, eds. Infectious Diseases of Fetus and Newborn. Toronto: WB Saunders, 1990:395-445.

2. Miller E, Cradock-Watson JE, Ridehalgh MKS. Outcome in newborn babies given varicella-zoster immunoglobulin after perinatal maternal infection with varicella-zoster virus. Lancet 1989;ii:371-3.

3. Zaia JA, Levin MJ, Preblud SR, et al. Evaluation of varicella-zoster immune globulin: protection of immunosuppressed children after household exposure to varicella. J infect Dis 1993;147:737-43.

4. Bakshi SS, Miller TC, Kaplan M, Hammerschlag MR, Prince A, Gershon AA. Failure of varicella-zoster immunoglobulin in modification of severe congenital varicella. Pediatr Infect Dis 1986:5:699-702.

5. King S, Gorensek M, Ford-Jones EL, Read SE. Fatal varicella-zoster infection in a newborn treated with varicella zoster immunoglobulin. Pediatr Infect Dis 1986;5:588-9.

6. Holland P, Isaacs D, Moxon ER. Fatal neonatal varicella infection. Lancet 1986;ii: 1156.

7. Gustafson TL, Shebab Z, Brunell PA. Outbreak of varicella in a neonatal intensive care nursery. Am J Dis Child 1984;138:548-50.

8. Rubin L, Leggiadro R, Elie MT, Lipsitz P. Disseminated varicella in a neonate: implications for immunoprophylaxis of neonates postnatally exposed to varicella. Pediatr Infect Dis 1986;5:100-2.

9. Wurzel CL, Rubin LG, Khilov LB. Varicella zoster immunoglobulin after postnatal exposure to varicella: survey of experts. Pediatr Infect Dis J 1987;6:466-8.

10. Gershon AA. Commentary. Pediatr Infect Dis J 1987;6:469-70.

11. Preblud SR, Bregman DJ, Vernon LL. Deaths from varicella in infants. Pediatr Infect Dis 1985;4:503-7.

12. Gold WL, Boulton JF, Goldman C, et al. Management of varicella exposures in the neonatal intensive care unit. Pediatr Infect Dis J 1993;12:954-5.

13. Canadian Pediatric Society. Statement on chickenpox: prevention and treatment. Can J Pediatr 1994;1:88-93.
A history of varicella is a reliable predictor of maternal immunity. In mothers who deny such a history, immune status can be established by a reliable laboratory technique such as ELISA or immunofluorescence. Most adults denying previous varicella infection are found to be seropositive, thus suggesting previous subclinical infection.

Hospitalized children exposed to varicella and given VZIG should be kept in strict isolation for 28 days after exposure since the prophylaxis is not $100 \%$ efficacious in disease prevention.

Other aspects of management of neonatal varicella can be found in a recently published statement of the Canadian Paediatric Society (13).

Canadian Paediatric Society Infectious Diseases and Immunization Committee

Members: Michael Hall (director responsible), St John's, Newfoundland; Noni E MacDonald (chairman), Department of Pediatrics, Children's Hospital of Eastern Ontario, Ottawa, Ontario; William Albritton, Provincial Laboratory of Public Health, Edmonton, Alberta; François Boucher, Département de pédiatrie, Centre Hospitalier Université Laval, Ste-Foy, Québec; Gilles Delage (principal author), Directeur scientifique, Laboratoire de Santé Publique du Québec,

Ste-Anne de Bellevue, Québec; Elizabeth Ford-Jones, Division of Infectious Diseases, The Hospital for Sick Children, Toronto, Ontario;

Susan King, Division of Infections Disease, The Hospital for Sick Children, Toronto, Ontario; David P Speert, Research Centre, Vancouver, British Columbia.

Ex-Officio Members: Frank R Friesen (Chair, Committee on Committees), Manitoba Clinic, Winnipeg, Manitoba.

Consultants: Ronald Gold, Division of Infectious Disease, The Hospital for Sick Children, Toronto, Ontario; Victor Marchessault, Department of Pediatrics, Children's Hospital of Eastern Ontario, Ottawa, Ontario.

Liaisons: Public Health, Jacqueline Carlson, Disease Control and Epidemiology, Public Health Branch, Toronto, Ontario; American Academy of Pediatrics, Larry Pickering, Eastern Virginia Medical School, Children's Hospital of the King's Daughters, Norfolk, Virginia; Centre for Vaccine Evaluation, David Scheifele, Division of Infectious Diseases, Research Centre, $B C^{\prime}$ 's Children's Hospital, Vancouver, British Columbia; Epidemiology, John Waters, Alberta Health, Communicable Disease Control, Edmonton, Alberta 


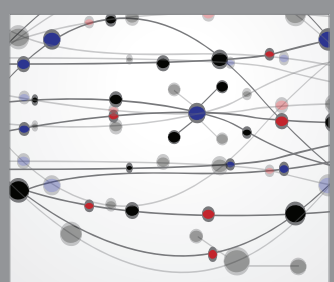

The Scientific World Journal
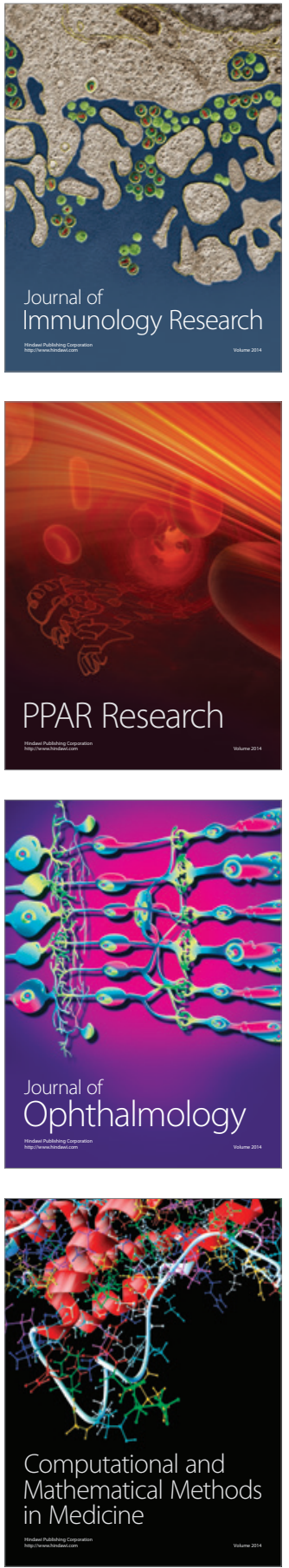

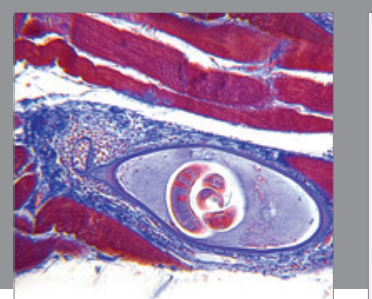

Gastroenterology Research and Practice

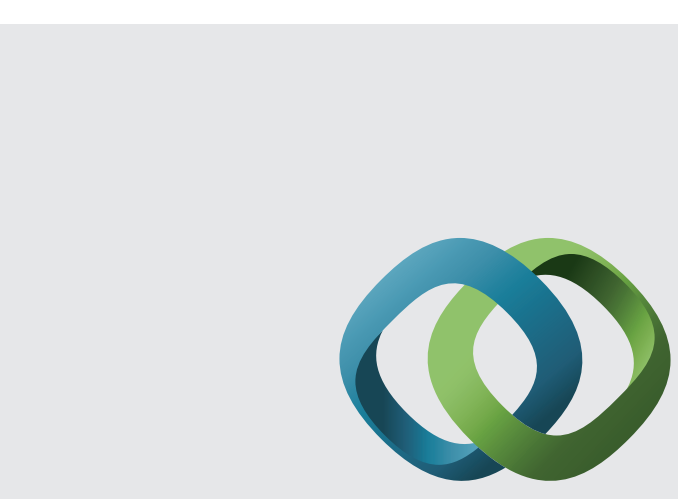

\section{Hindawi}

Submit your manuscripts at

http://www.hindawi.com
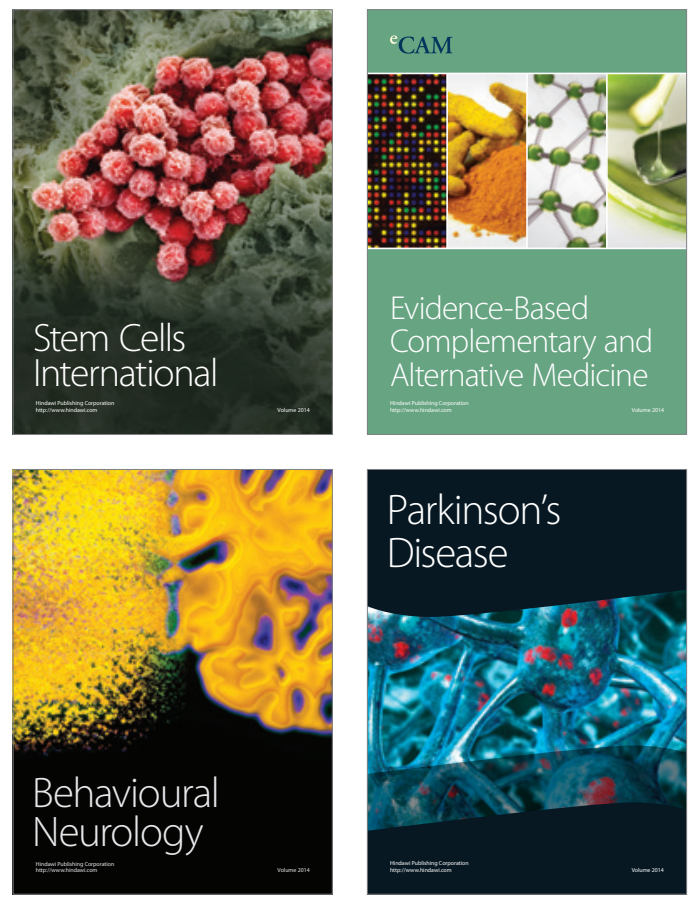
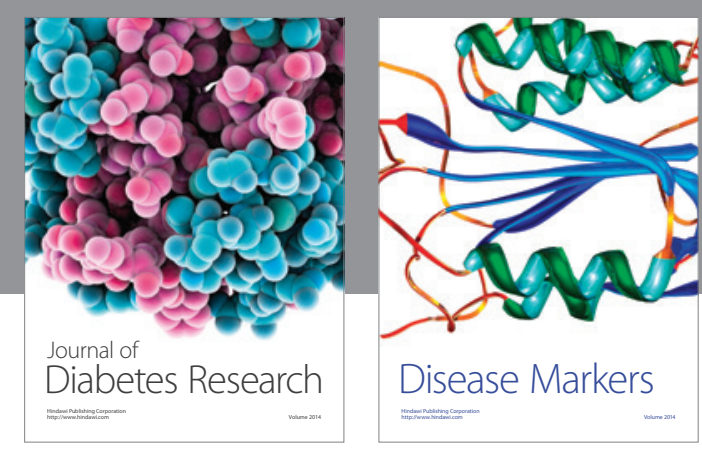

Disease Markers
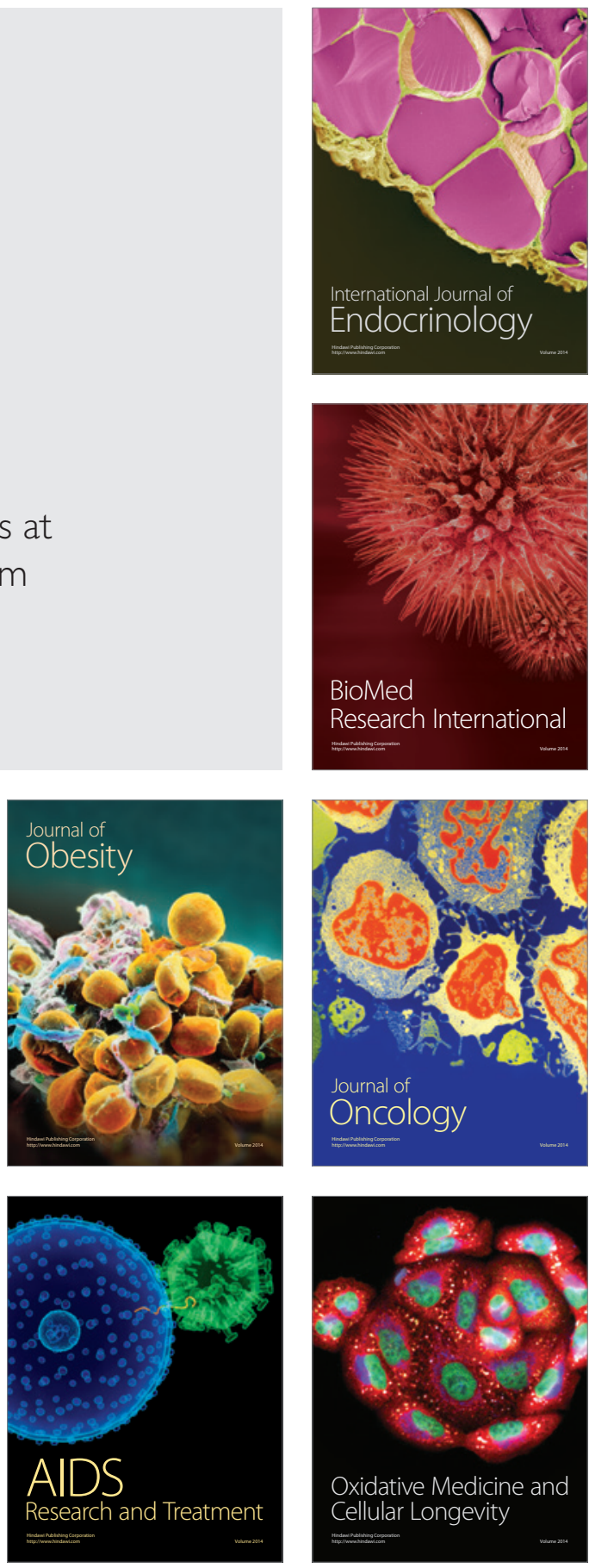